\title{
Leftovers in seed dispersal: ecological implications of partial seed consumption for oak regeneration
}

\author{
Ramón Perea, Alfonso San Miguel and Luis Gil* \\ Departamento de Silvopascicultura, ETSI de Montes, Universidad Politécnica de Madrid, Ciudad Universitaria s/n, \\ 28040 Madrid, Spain
}

\begin{abstract}
Summary
1. Successful seed dispersal by animals is assumed to occur when undamaged seeds arrive at a favourable microsite. Most seed removal and dispersal studies consider only two possible seed fates, predation or escape intact. Whether partial consumption of seeds has ecological implications for natural regeneration is unclear. We studied partial consumption of seeds in a rodent-dispersed oak species.

2. Fifteen percent of dispersed acorns were found partially eaten in a field experiment. Most damage affected only the basal portion of the seeds, resulting in no embryo damage. Partially eaten acorns had no differences in dispersal distance compared to intact acorns but were recovered at farther distances than completely consumed acorns.

3. Partially eaten acorns were found under shrub cover unlike intact acorns that were mostly dispersed to open microhabitats.

4. Partially eaten acorns were not found buried proportionally more often than intact acorns, leading to desiccation and exposure to biotic agents (predators, bacteria and fungi). However, partial consumption caused more rapid germination, which enables the acorns to tolerate the negative effects of exposure.

5. Re-caching and shrub cover as microhabitat of destination promote partial seed consumption. Larger acorns escaped predation more often and had higher uneaten cotyledon mass. Satiation at seed level is the most plausible explanation for partial consumption.

6. Partial consumption caused no differences in root biomass when acorns experienced only small cotyledon loss. However, root biomass was lower when acorns experienced heavy loss of tissue but, surprisingly, they produced longer roots, which allow the seeds to gain access sooner to deeper resources.

7. Synthesis. Partial consumption of acorns is an important event in the oak regeneration process, both quantitatively and qualitatively. Most acorns were damaged non-lethally, without decreasing both dispersal distances and the probability of successful establishment. Faster germination and production of longer roots allow partially eaten seeds to tolerate better the exposure disadvantages caused by the removal of the pericarp and the non-buried deposition. Consequently, partially consumed seeds can contribute significantly to natural regeneration and must be considered in future seed dispersal studies.
\end{abstract}

Key-words: Apodemus sylvaticus, burial, dispersal, dispersal distance, embryo damage, germination, microhabitat, predator satiation, Quercus pyrenaica, root system

\section{Introduction}

Predation by animals is a common fate of seeds and reduces plant reproduction efficiency (Vander Wall 2001). Seed predation is also considered an important selective pressure, driving

*Correspondence author. E-mail: 1uis.gil@upm.es the evolution of seed characteristics (Janzen 1969). Dispersal of whole intact seeds and seed predation have been extensively studied in plant regeneration (Vander Wall 2001; Herrera \& Pellmyr 2002; Forget et al. 2005 and references therein). Although rarely studied, partial consumption of seeds has been reported for many plant species across temperate and tropical ecosystems (Steele et al. 1993; Ollerton \& Lack 1996; VallejoMarín, Domínguez \& Dirzo 2006). Partial seed predation 
reduces the amount of reserves and, thus, causes negative effects on seed survival and seedling establishment (Westoby, Jurado \& Leishman 1992). Nevertheless, it has also been demonstrated that partially eaten seeds can still germinate if the embryo remains intact (Steele et al. 1993; Branco et al. 2002; Pérez et al. 2008) and can even establish successfully (Andersson \& Frost 1996; Xiao, Harris \& Zhang 2007). However, most dispersal studies fail to consider partial seed predation as an alternative to the two common fates (intact or eaten), usually assuming partial consumption of seeds as equivalent to seed death. As a result, past studies have neglected to explore the dispersal patterns and effectiveness of partially consumed seeds in the reproductive success of plants.

Acorns have high nutritional value and are attractive for many seed foragers (Den Ouden, Jansen \& Smit 2005). Partial consumption of acorns has been extensively recorded for invertebrates, mainly weevil larvae (Oliver \& Chapin 1984; Branco et al. 2002; Bonal, Muñoz \& Díaz 2007; Xiao, Harris \& Zhang 2007), and vertebrates, especially jays and squirrels (Steele et al. 1993; Steele, Gavel \& Bachman 1998), but also wood mice (Pons \& Pausas 2007). Plausible explanations for partial acorn consumption include higher tannin concentration around the embryo (Steele et al. 1993) or large seed size that satiates weevil larvae (Bonal, Muñoz \& Díaz 2007). In addition, seed shape (geometry) was found to promote partial consumption of the basal portion (Steele, Galve \& Bachman 1998).

Rodents are known to contribute to natural regeneration in many oak forests and woodlands by dispersing the acorns to suitable sites for germination and establishment (Crow 1988; Steele et al. 2007; Gómez, Puerta-Piñeiro \& Schupp 2008). Moreover, Steele, Gavel \& Bachman (1998) observed that grey squirrels regularly cache apical fragments after partial predation. Notwithstanding, dispersal patterns of partially eaten acorns, including both quantitative and qualitative aspects, remain elusive. Quantitatively, Steele, Gavel \& Bachman (1998) found that not only tannin content influences the proportion of partially eaten seeds but also other factors such as food availability. However, we still ignore whether other factors such as vegetation structure or rodent behaviour, which significantly affect seed encounter and dispersal (Hulme 1994; Vander Wall \& Joyner 1998), may determine the proportion of seeds affected by partial consumption. Qualitatively, seed deposition (microhabitat quality for recruitment) and dispersal distances, which determine demographic and genetic structure, are essential for understanding the effectiveness (sensu Schupp 1993) and the ecology of seed dispersal (Vander Wall 2001). Possible changes in both quantitative and qualitative aspects of the dispersal, due to partial seed consumption, have not been explored but may be crucial to understand more thoroughly the process of natural regeneration. Therefore, there is a need for an integrative approach to address the dispersal of partially consumed seeds, from the causative factors of partial seed consumption (not only intrinsic seed characteristics but also ecological factors), to the establishment of a new seedling, including seed survival, dispersal distances, seed deposition and germination rates.
The objective of this investigation was to study partial consumption of acorns by their main dispersing rodent in Europe, the wood mouse Apodemus sylvaticus L. (Den Ouden, Jansen $\&$ Smit 2005; Suchomel 2008) in a submediterranean oak forest in central Spain. More specifically, we aimed to quantify the partial consumption of acorns and study some of the potential factors that may be involved in partial seed consumption, both intrinsic (acorn weight) and ecological (microhabitat of origin and destination and number of dispersal movements). Then, we examined whether deposition distances differ between intact seeds, completely consumed seeds and partially eaten seeds. Quality of seed deposition (burial depth, litter cover and microsite) was also assessed for intact and partially eaten seeds. Finally, we examined the effects of partial consumption on germination and seedling establishment at increasing levels of simulated partial predation. By integrating all these aspects from seed offer to seedling establishment, we were able to assess the ecological implications of partial seed consumption in the natural regeneration of oaks.

\section{Material and methods}

\section{STUDY AREA}

This study was conducted in a mixed oak stand of Quercus pyrenaica Willd. and Quercus petraea (Matt.) Liebl. (380 stems ha ${ }^{-1}$; basal area $22.21 \mathrm{~m}^{2} \mathrm{ha}^{-1}$ ) with scattered European beech Fagus sylvatica L. (83 stems $\mathrm{ha}^{-1}$; basal area $\left.0.79 \mathrm{~m}^{2} \mathrm{ha}^{-1}\right)$. The understorey is formed mainly by a few shrub species (Erica arborea $\mathrm{L}$., Ilex aquifolium $\mathrm{L}$., Genista florida L., Crataegus monogyna Jacq., Rubus ulmifolius Schott and Rosa sp.). The study area is located in the Ayllon mountain range in central Spain ( $3^{\circ} 30^{\prime} \mathrm{W}, 41^{\circ} 07^{\prime} \mathrm{N}$, Madrid province), at $1400 \mathrm{~m}$ a.s.l., under a submediterranean climate with $958 \mathrm{~mm}$ annual rainfall and a 2-month summer dry season. The forest is a mosaic of mixed to pure stands of variable density (Pardo, Gil \& Pardos 2004) with generally a large proportion of stems below $30 \mathrm{~cm}$ d.b.h. Wood mouse is the main acorn disperser in the study area with an estimated density of 14 individuals ha ${ }^{-1}$ in autumn 2008 (R. Perea, unpublished data).

\section{FIELD EXPERIMENT}

All $Q$. pyrenaica seeds were collected in the study area or in nearby locations during the first fortnight of October 2008 and 2009. To detect and then discard of empty and insect-infested seeds, acorns were floated in water for $24 \mathrm{~h}$. All experiments were carried out with sound acorns only. A wire ( $3 \mathrm{~cm}$ long and $0.6 \mathrm{~mm}$ wide) was attached to the acorns by drilling a hole with a needle in the approximate centre of the side of the acorn and as close as possible to the pericarp to use as little wire as possible and to disturb the animal the least. Then, a $14.5 \times 1.2 \mathrm{~cm}$ yellow plastic tag was attached to the wire and numbered with waterproof permanent ink. We used this wire tagging method because Xiao, Jansen \& Zhang (2006) found that it does not significantly alter acorn dispersal patterns and yields a high recovery rate. Wire plus tag constituted $6.7-11.8 \%$ of the acorn weight. Since shrub cover plays an important role in rodent activity (Manson \& Stiles 1998) we considered two microhabitats for offering acorns: under oak trees with no shrub cover within a 5 -m radius (only litter) and under shrub cover beneath oak-trees. Four sites were chosen and each site contained two acorn supply stations, one for each microhabitat. Distances between sites were at least $200 \mathrm{~m}$ to avoid overlapping 
sites for rodents and ensure statistical independence. Stations were located at 7-10 $\mathrm{m}$ from each other and were built with a wire mesh $(0.5 \mathrm{~m} \times 0.5 \mathrm{~m})$, placed approximately $3 \mathrm{~cm}$ above the ground surface to exclude removers other than small mammals. Digital video cameras with night vision (Leaf River IR-5, 5.0 MP) were used in two stations in autumn 2009 to confirm that wood mice were indeed the only acorn removers.

Each autumn, two groups of 40 tagged acorns of a broad range of weights (2-12 g excluding wire and tag) were placed on the ground in each station. The first group ( 40 acorns) was placed in October, the second (40 acorns) in November. In total, 1280 acorns were offered to the rodents ( 8 stations $\times 2$ years $\times 2$ groups $\times 40$ acorns). We monitored seed removal and searched for caches daily during the first 10 days after seed offer and then every 3 days until day 25-31. Tag number, distance from the supply station, burial depth, microhabitat (shrub vs. open) and category (intact, completely consumed, partially eaten) were recorded for each relocated acorn. For the partially eaten acorns we recorded the region damaged (pericarp, basal, lateral or apical portion), the approximate percentage of cotyledon loss (visual estimate, using wire position as reference of $50 \%$ ) and the embryo status (damaged or not). Caches were marked with wooden sticks $(50 \mathrm{~cm} \times 0.5 \mathrm{~cm})$ to allow easy relocation. Marked sticks have no significant effect on seed removal (Xiao, Zhang \& Wang 2005). We also covered the yellow plastic tags with litter to avoid attracting foragers. Every day of fieldwork we monitored previously found caches and noted whether acorns were still present.

\section{GERMINATION EXPERIMENT}

We collected 180 Q. pyrenaica acorns and divided them into six groups of 30 acorns. Two sizes (large: $6.5-8.5 \mathrm{~g}$ and small: $3.0-5.0 \mathrm{~g}$ ) and three simulated consumption categories (intact, heavily eaten and slightly eaten acorns) were established. To simulate heavily and slightly eaten acorns were cut-off two-thirds and one-third of the acorn length, respectively. Acorns were reweighed after cotyledon removal and sown in December 2009. Intact and cut acorns were placed in trays with drainage holes and half-covered by perlite. Acorns were moistened by maintaining water under the trays. All trays were kept at the same environmental conditions in a germination chamber: $60 \%$ humidity, $14 \mathrm{~h}$ of light per day at $24{ }^{\circ} \mathrm{C}$ and $10 \mathrm{~h}$ in darkness at $19^{\circ} \mathrm{C}$. Successful germination was declared when a radicle longer than $2 \mathrm{~cm}$ had formed. Trays were checked three times a week for 14 weeks.

\section{ESTABLISHMENT EXPERIMENT}

We assigned a total number of 180 Q. pyrenaica acorns to individual containers of $300 \mathrm{~mm}$ length and $50 \mathrm{~mm}$ diameter. Acorns were divided into six groups with 30 acorns per group according to the same criteria (size and simulated consumption categories) as in the germination experiment. Acorns were immersed in water for $48 \mathrm{~h}$ to rehydrate them and sown in October 2009 into a substrate consisting of peat and perlite in a 3:1 proportion. Acorns were partially covered in substrate $(1-2 \mathrm{~cm})$ and kept under the same environmental conditions as described in the germination experiment, except the sown seeds were watered three times a week. Containers were checked three times a week during approximately 4 months for the appearance of photosynthetic tissue above the substrate level and taken out from the chamber once the stem was longer than $1 \mathrm{~cm}$. We removed the root from each seedling and measured the root length and root diameter at the root collar. Then we washed all roots, dried them in an oven at $80^{\circ} \mathrm{C}$ for $48 \mathrm{~h}$ and weighed them.

\section{DATA ANALYSIS}

We ran two Generalized Linear Mixed Models (GLMM) to analyse acorn fate. We took a binary response variable, first to compare partial consumption with complete predation (M1) and second to compare partial consumption with intact acorns (M2). Fixed effects were acorn weight, number of movements (re-caches), microhabitat of origin and microhabitat of destination. Random effects were those considered in the nested structure (site nested within year). Acorn weight was the sum of acorn, wire and tag weights. Linear Mixed Models were used to analyse the effects on dispersal distance (M3). We fitted the response variable (distance to supply stations) to a normal distribution by a log-transformation. We included acorn category, number of dispersal movements and acorn weight as fixed effects. Deposition conditions (buried vs. not buried and within the litter vs. on the litter) were analysed with GLMM in relation to acorn category (partially eaten vs. intact). To analyse the effects on burial depth, we removed the values equal to zero in the burial depth response variable. We built the same model as the distance model (log-transformed) including distance as fixed effect. All models were performed using the R 2.8.1 software. To find the best fit model we simplified the model using parsimony criteria (Crawley 2007).

To analyse whether germination and establishment are affected by partial consumption, we performed a two-way ANOvA. Factors were acorn size (large and small) and artificial cotyledon loss (intact, heavily and slightly eaten), and response variables were time to start germination, root length, dry root biomass and time to produce green tissue. ANOVA with data subsets were performed when the interaction between the main factors was found. Tukey's HSD post hoc tests were performed for multiple comparisons. Generalized linear models were used to analyse acorn germination (germinated vs. non-germinated), taking acorn size and simulated consumption category as factors. To find what variable best explains root biomass, root length and time in establishment, we used linear regressions.

\section{Results}

A total of 142 video recordings were obtained. No removers other than wood mice were recorded taking acorns from the supply points. Partially eaten acorns accounted for $23.3 \%$ $(N=110)$ of the relocated acorns and only $10.0 \%(N=11)$ of them resulted in non-viable seeds (Fig. 1). Damage was found in all regions of the acorn, even affecting only the pericarp (Table 1). Most partially eaten acorns were found damaged in the basal portion, followed by acorns damaged only in the lateral portion (Table 1). Uneaten cotyledon mass was positively correlated to acorn original weight (Fig. 2).

\section{FACTORS AFFECTING CONSUMPTION}

Remaining intact or being partially eaten was not affected by either microhabitat of origin or acorn weight (Table 2). More recaching resulted in significantly higher partial consumption and fewer intact acorns (Table 2). In areas under shrub cover, significantly more partially eaten and fewer whole cached acorns were found (Table 2).

Microhabitat of origin had no significant influence on whether an acorn was partially eaten or completely consumed. However, acorn weight resulted in significant effects (Table 2): lighter acorns were significantly more likely to be completely 


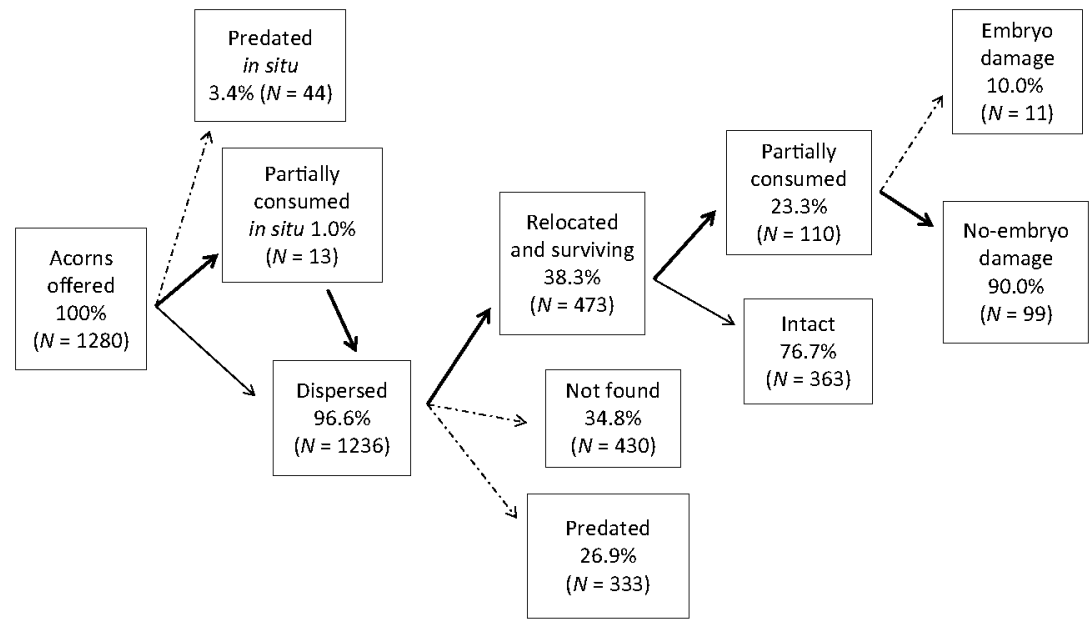

Fig. 1. Diagram of seed fate, showing the percentages and number of seeds for each fate category. Bold arrows indicate the fate for partially consumed seeds and dashed arrows for non-viable or not found seeds. Data for both autumns together (2008 and 2009).
Table 1. Percentage (\%) and number of acorns $(N)$ for different damage locations caused by wood mice in partially eaten acorns. Cotyledon loss is shown for each damage location, estimated in percentage of acorn volume loss

\begin{tabular}{lrrc}
\hline Damage location & $\%$ & $N$ & $\begin{array}{l}\text { Cotyledon } \\
\text { loss }(\%)(\bar{x} \pm \mathrm{SE})\end{array}$ \\
\hline Basal & 50.0 & 55 & $36.6 \pm 19.2$ \\
Lateral & 17.3 & 19 & $39.4 \pm 13.1$ \\
Basal \& Lateral & 11.8 & 13 & $57.2 \pm 19.4$ \\
Pericarp & 10.0 & 11 & $0.0 \pm 0.0$ \\
Apical & 6.4 & 7 & $22.0 \pm 11.5$ \\
Apical \& Lateral & 2.7 & 3 & $42.5 \pm 31.9$ \\
Apical \& Pericarp & 0.9 & 1 & 5.0 \\
Basal \& Lateral \& & 0.9 & 1 & 35.0 \\
$\quad$ Pericarp & & & \\
\hline
\end{tabular}

consumed instead of being partially eaten. More dispersal movements resulted in higher significant predation (Table 2). No shrub cover (open) as microhabitat of destination significantly increased the probability for acorns to be partially eaten instead of being completely consumed (Table 2).

\section{DISPERSAL DISTANCES}

Partially eaten acorns and intact acorns were located at similar distances from the supply station (Table 3) $(t=-0.346$; $P=0.730$ ). Viable acorns (both partially eaten and intact ones) were found at further dispersal distances than completely consumed acorns (Table 3$)(t=-3.382 ; P<0.001)$.

\section{SEED DEPOSITION CONDITIONS}

Partially eaten acorns $(61.8 \% ; N=68)$ were found under shrub cover more frequently than intact acorns $(30.7 \%$; $N=112)\left(\chi^{2}=45.462 ; P<0.001\right)$. Instead of being buried, partially eaten acorns were mostly placed on the ground $(62.8 \% ; N=69)$, resulting in significant differences compared to intact acorns which were mostly buried $(69.1 \% ; N=251$; $Z=-4.220 ; P<0.001)$. Among those acorns placed on the



Fig. 2. Relationship between original acorn weight (before dispersal) and estimated acorn weight after partial predation by rodents.

ground, partially eaten ones were found on the litter $(36.4 \%$; $N=40)$ rather than within the litter $(26.4 \% ; N=29)$. However, intact acorns were placed within the litter $(20.7 \%$; $N=75)$ rather than on the litter $(10.2 \% ; N=37)$, resulting in significant differences $(Z=-2.773 ; P=0.006)$. Intact acorns were buried deeper (mean $\pm \mathrm{SE}=21 \pm 25 \mathrm{~mm}$; median $=12 \mathrm{~mm}$; range $=1-118 \mathrm{~mm} ; N=251$ ) than partially eaten acorns (mean $\pm \mathrm{SE}=15 \pm 13 \mathrm{~mm}$; median $=10 \mathrm{~mm}$; range $=1-47 \mathrm{~mm} ; N=40$ ) but no significant effects were found $(t=-0.445 ; P=0.657)$.

\section{GERMINATION EXPERIMENT}

Acorn germination rate was $96.7 \%(N=174$, Table 4$)$. Acorn germination (germinated vs. non-germinated acorns) was not affected by either acorn size $(Z=0.898 ; P=0.369)$ or category of artificial consumption $(Z=0.006 ; P=0.995)$. However, time to germination was affected by consumption category $\left(F_{2,170}=50.838 ; P<0.001\right)$ but not by acorn size $\left(F_{1,170}=1.020 ; P=0.315\right)$. Multiple comparisons revealed that simulated partially eaten acorns germinated significantly sooner than intact acorns $(P<0.001$ for both slightly and heavily eaten vs. intact). However, simulated slightly eaten and 
Table 2. Summary of the models to test the variables affecting partial consumption vs. intact acorns (M1) and partial consumption vs. complete predation of acorns (M2). Microhabitat of origin and destination are shown for shrub cover compared to open

\begin{tabular}{|c|c|c|c|c|c|c|}
\hline & \multicolumn{3}{|c|}{ M1. Partial consumption vs. intact } & \multicolumn{3}{|c|}{ M2. Partial consumption vs. predated } \\
\hline & Estimate $\pm \mathrm{SE}$ & $Z$-value & $P$-value & Estimate $\pm \mathrm{SE}$ & $Z$-value & $P$-value \\
\hline Microhabitat of origin (shrub) & $-0.208 \pm 0.296$ & 0.296 & 0.482 & $0.521 \pm 0.343$ & 1.520 & 0.128 \\
\hline Acorn weight & $0.037 \pm 0.063$ & 0.590 & 0.555 & $0.165 \pm 0.065$ & 2.526 & 0.011 \\
\hline Number of re-caches & $0.563 \pm 0.182$ & 3.087 & 0.002 & $-0.532 \pm 0.191$ & -2.783 & 0.005 \\
\hline Microhabitat of destination (shrub) & $1.242 \pm 0.289$ & 4.297 & $<0.001$ & $-1.639 \pm 0.319$ & -5.133 & $<0.001$ \\
\hline
\end{tabular}

M1: AIC $=346.5 ;$ Deviance $=332.5$. M2: AIC $=319.7$; Deviance $=307.7$

Bold type indicates statistical significance.

Table 3. Distances to supply stations for acorn categories in all dispersal movements

\begin{tabular}{lccccc}
\hline Acorn category & $N$ & Mean \pm SE $(\mathrm{m})$ & Median $(\mathrm{m})$ & Minimum $(\mathrm{m})$ & Maximum $(\mathrm{m})$ \\
\hline Intact & 361 & $20.37 \pm 21.47$ & 13.60 & 0.07 & 126.10 \\
Partially eaten & 110 & $20.34 \pm 26.68$ & 13.42 & 0.10 & 132.15 \\
Completely consumed & 333 & $11.79 \pm 11.99$ & 8.36 & 0.10 & 82.00 \\
\hline
\end{tabular}

Table 4. Acorn germination percentage and time to start germination (mean $\pm \mathrm{SE}$ ) for different levels of simulated partial predation

\begin{tabular}{|c|c|c|c|c|c|c|}
\hline & \multicolumn{3}{|c|}{$\begin{array}{l}\text { Small acorns } \\
(3.00-5.00 \mathrm{~g})\end{array}$} & \multicolumn{3}{|c|}{$\begin{array}{l}\text { Large acorns } \\
(6.50-8.50 \mathrm{~g})\end{array}$} \\
\hline & $\%$ & $N$ & $\begin{array}{l}\text { Time to } \\
\text { germinate } \\
\text { (days) }\end{array}$ & $\%$ & $N$ & $\begin{array}{l}\text { Time to } \\
\text { germinate } \\
\text { (days) }\end{array}$ \\
\hline Intact & 87 & 26 & $45 \pm 23$ & 93 & 28 & $54 \pm 25$ \\
\hline Slightly eaten & 100 & 30 & $9 \pm 5$ & 100 & 30 & $9 \pm 7$ \\
\hline Heavily eaten & 100 & 30 & $9 \pm 13$ & 100 & 30 & $16 \pm 20$ \\
\hline
\end{tabular}

heavily eaten acorns showed no differences in time to germination $(P=0.675)$.

\section{ESTABLISHMENT EXPERIMENT}

The percentage of acorns producing photosynthetic tissue after sowing was $91.1 \%(N=164)$. Root biomass was significantly affected by both acorn size and degree of consumption (Fig. 3). Multiple comparisons indicated that intact and simulated slightly eaten acorns had no significant differences in root biomass ( $P=0.251)$. However, simulated heavily eaten acorns produced lower root biomass (Fig. 3) and showed significant differences with respect to simulated slightly eaten $(P=0.024)$ and intact acorns $(P<0.001)$. Root biomass was strongly related to cotyledon mass in linear regressions [Root biomass $=0.0753+0.0184 \times$ (uneaten mass); $t=$ 5.342; $P<0.001$; Adjust $\left.-R^{2}=0.25\right]$.

Root length was affected by neither acorn size $\left(F_{1,158}=2.44 ; P=0.123\right)$ nor simulated consumption category $\left(F_{2,158}=0.22 ; P=0.805\right)$ alone as main effects, but the interaction between both factors was found significant $\left(F_{2,158}=3.78 ; P=0.027\right)$. Surprisingly, large acorns showed longer root length when heavily eaten, then when slightly eaten

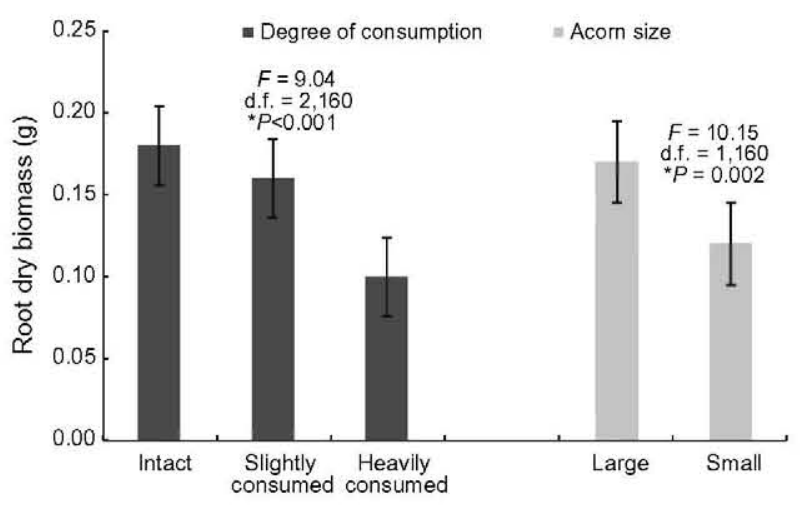

Fig. 3. Mean $\pm \mathrm{SE}$ values of root dry biomass for both main factors (degree of consumption and acorn size). No significant interaction between factors was found. Asterisks indicate significant differences among the factor levels.

and finally shorter root length when intact, obtaining significant differences in root length for the different levels of simulated consumption (Fig. 4). However, for small acorns we found no differences in root length among the three treatments of simulated consumption (Fig. 4). Unlike root biomass, root length was not related to the uneaten cotyledon mass $(t=-0.266 ; P=0.790)$. The variable that correlated strongest with root length was the loss of cotyledon mass, although very little is explained [Root length $(\mathrm{mm})=166.528+$ $6.371 \times$ (eaten cotyledon mass in $\mathrm{g}$ ); $t=1.459 ; P=0.148$; Adjust- $\left.R^{2}=0.014\right]$.

Time to produce the first photosynthetic tissue was significantly affected by simulated consumption category $\left(F_{2,160}=\right.$ 6.97; $P=0.002)$ but not by acorn size $\left(F_{1,160}=0.81\right.$; $P=0.447$ ). Multiple comparisons showed that simulated heavily eaten acorns required significantly more time ( $28 \pm 13$ days) to produce photosynthetic tissue than simulated slightly eaten and intact acorns [21 \pm 4 days 


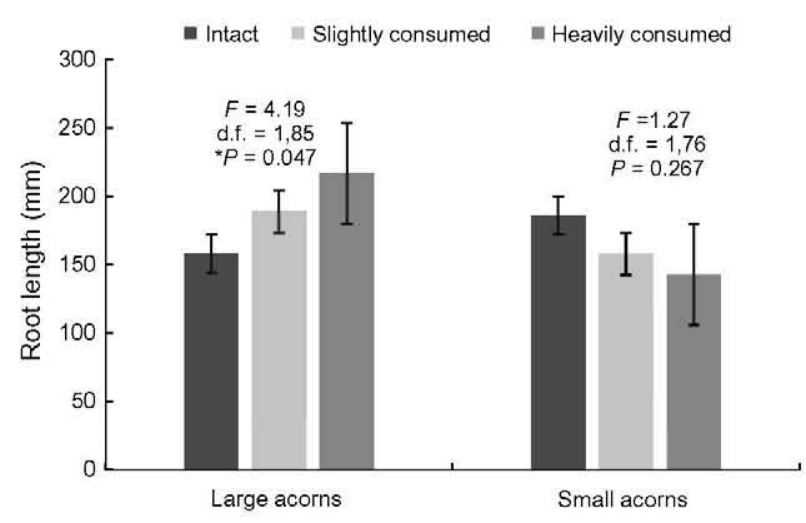

Fig. 4. Mean \pm SE values of root length produced for large and small acorns with different levels of simulated partial predation. Asterisks indicate significant differences among the different degrees of simulated consumption.

$(P=0.006)$ and $20 \pm 5$ days $(P=0.001)$, respectively]. However, simulated slightly eaten and intact acorns showed no differences $(P=0.969)$. Time to establish was better explained by root length [time (days) $=15.902+0.038 \times$ (root length in mm); $t=3.694 ; \quad P<0.001$; Adjust$\left.R^{2}=0.15\right]$ than by root biomass $(t=1.896 ; P=0.061$; Adjust- $R^{2}=0.03$ ).

\section{Discussion}

This study contributes to the understanding of dispersal ecology of seeds. First, partial consumption of seeds, while usually considered fatal, can be an important mechanism in seed dispersal both quantitatively and qualitatively. We give a first quantification of partial consumption of acorns by rodents and found that most seeds were damaged in non-vital parts, leading to germination and the possibility of establishment. Secondly, we found that not only intrinsic seed characteristics (as seed size) but also microhabitat structure (shrub cover) and animal behaviour (number of repeated dispersal movements) influence the likelihood that seeds will be partially consumed. Thirdly, slightly partially eaten seeds were found to contribute to the regeneration process without decreasing both dispersal distances and the probability of successful establishment. This study also demonstrates for the first time that partial consumption of seeds alters the quality of seed deposition (burial, litter cover and microhabitat). This, together with differences in the start of germination (sooner for partially consumed seeds) and in the root length (longer for partially eaten seeds) leads to the possibility of germination and seedling performance under different ecological conditions. Thus, partial consumption of seeds has ecological implications that eventually affect natural regeneration patterns.

\section{ACORN DAMAGE WAS FOUND IN NON-EMBRYONIC TISSUE}

Most of the seed damage caused by partial consumption was found in non-vital parts of the propagule (outside of the embryo). The preference of rodents to damage acorns away from the apical portion has been explained by seed geometry and a higher content of tannins in that part (Steele, Gavel \& Bachman 1998). In this study, larger acorns escaped complete predation more easily and had higher uneaten cotyledon mass when partially eaten (Fig. 2). This agrees with the satiation hypothesis at the seed level, which has been rarely taken into consideration for vertebrates. Production of large seed crops has been considered almost the only satiation mechanism (Janzen 1971; Crawley \& Long 1995). However, here we suggest that larger acorns (up to $13 \mathrm{~g}$ ) can satiate wood mice (up to $36 \mathrm{~g}$ ) more efficiently, increasing the possibility that the embryo remains undamaged. Thus, larger acorns offer a possible evolutionary advantage, not only to satiate granivorous insects (Bonal, Muñoz \& Díaz 2007) but also small mammals.

\section{NOT ONLY SEED TRAITS CAUSE PARTIAL CONSUMPTION}

Although larger seeds were proportionally more affected by partial consumption, other factors such as microhabitat structure correlated with the higher proportion of partial consumption. Acorns that were dispersed under shrub cover were more likely to be partially eaten, probably because more cover leads to higher rodent activity and lower predation risk (Den Ouden, Jansen \& Smit 2005) and provides more time for rodents to feed. In addition, acorns that are moved repeatedly have a higher probability to be partially eaten but also to be completely consumed. However, a higher number of movements causes increasing dispersal distances and improves dispersal quality (Vander Wall \& Joyner 1998).

\section{PARTIAL SEED CONSUMPTION DOES NOT AFFECT DISPERSAL DISTANCES}

Partially consumed acorns were found dispersed outside of the tree shadow, where the probability of successful recruitment is higher (Vander Wall 2001). In this study we demonstrated that dispersal distances do not significantly differ when acorns are partially eaten compared to intact acorns. To our knowledge, this comparison in dispersal distances between partially eaten and intact seeds is reported for first time. Other studies compared distances between intact and consumed seeds. For acorns, Xiao, Zhang \& Wang (2005) found no differences in dispersal distances between predated and intact acorns. However, in this investigation, distances for predated acorns were significantly shorter. Our study reveals that seed fate and dispersal distance are not independent, probably due to microhabitat selection by rodents, i.e. selection of safe feeding sites.

\section{PARTIALLY EATEN SEEDS WERE FOUND MOSTLY UNDER SHRUB COVER}

Seed deposition in an appropriate microhabitat of destination can enhance dispersal quality (Schupp 1993). Partially eaten acorns were found under shrub cover more frequently than intact acorns. This differential microhabitat of deposition could offer some ecological advantages, especially under xeric 
conditions, improving the quality of seed destination through plant facilitation (Gómez-Aparicio et al. 2004). In Mediterranean conditions, shrub cover reduces evapotranspiration and protects seedlings from browsing (Pulido \& Díaz 2005). On the other hand, shrubs can compete with seedling during the first stages of seedling development (Lorimer, Chapman \& Lambert 1994). Thus, shrub cover may be detrimental to germination and establishment under more humid conditions ( $\mathrm{Li} \&$ Ma 2003), such as those found in temperate oak forests.

\section{PARTIALLY EATEN SEEDS ARE LESS FREQUENTLY BURIED}

Partially eaten seeds were found on the ground proportionally more often than intact acorns. This non-buried destination may negatively affect the quality of the germination site, leading to higher desiccation and exposure to biotic agents (predators, fungi and bacteria). Furthermore, partially consumed seeds were mostly found on the litter unlike intact acorns that were found within the litter. Litter cover provides humidity and shelter against predators, two positive aspects for survival and germination of acorns (García, Bañuelos \& Houle 2002). Thus, regarding burial conditions, partial consumption seems to be detrimental.

\section{FASTER GERMINATION AND LONGER ROOT LENGTH}

We observed higher germination rates for partially eaten seeds than for intact seeds in agreement with other studies (Steele et al. 1993). More rapid germination was found for partially eaten seeds. This faster germination has been attributed to physiological responses to the removal of seed coat or other barriers to imbibitions (Vallejo-Marín, Domínguez \& Dirzo 2006; Pérez et al. 2008). Such a mechanism of faster germination allows partially consumed seeds to better tolerate the exposure disadvantages caused by the removal of the pericarp and the non-buried deposition.

This study also provides evidence that seedling establishment is significantly affected only under heavy partial consumption. Acorns that are slightly damaged (up to one-third of cotyledon length) can establish and produce similar root biomass to intact acorns. This fact demonstrates that cotyledon mass may act not only for establishment but also as an extra energy for other purposes (e.g. predator satiation). Other studies revealed that acorns with partially reduced cotyledons can establish successfully (Andersson \& Frost 1996; Branco et al. 2002). However, when acorns are heavily eaten (twothirds of the acorn length) root biomass is significantly lower and could limit reproduction success.

Surprisingly, root length was positively related to increasing degrees of consumption when seeds were large. Thus, acorns respond differently after partial consumption, probably because the germination process is accelerated when seeds are damaged (faster imbibition). This response allows acorns to reach deeper located resources sooner. However, small acorns did not show such a root length pattern for different levels of consumption, probably due to the reduced cotyledon mass, indicating a possible threshold at which partially eaten acorns are not even able to produce root length/biomass.

We conclude that tolerance to partial seed consumption is an important reproductive strategy, which enables recruitment in oaks. In this study, we only analysed a few potential factors affecting partial seed consumption. Whether partial consumption of seeds by vertebrates is related to other factors (e.g. seed phenology, predator size or pilfering behaviour) deserves further attention. We recommend future studies on seed traits and animal behaviour to fully understand the origin and ecology of partial seed predation.

\section{Acknowledgements}

We would like to thank Steve B. Vander Wall and Christopher M. Moore for numerous suggestions and English corrections, Rocío González for her assistance in field and laboratory work, Jesús Alonso for helping us with fieldwork and Mariana Fernández and María Martínez for their valuable comments in data analysis. R.P. is supported by a Ph.D. grant from Universidad Politécnica de Madrid. This study was funded by the Comunidad Autonoma de Madrid and the project AGL2006-00813 of the Spanish CICYT.

\section{References}

Andersson, C. \& Frost, I. (1996) Growth of Quercus robur seedlings after experimental grazing and cotyledon removal. Acta Botanica Neerlandica, $\mathbf{4 5}$, $85-94$.

Bonal, R., Muñoz, A. \& Díaz, M. (2007) Satiation of predispersal seed predators: the importance of considering both plant and seed level. Evolutionary Ecology, 21, 367-380.

Branco, M., Branco, C., Merouani, H. \& Almeida, M.H. (2002) Germination success, survival and seedling vigour of Quercus suber acorns in relation to insect damage. Forest Ecology and Management, 166, 159-164.

Crawley, M.J. (2007) The R book. Wiley Editorial, England.

Crawley, M.J. \& Long, C.R. (1995) Alternate bearing, predator satiation and seedling recruitment in Quercus robur L. Journal of Ecology, 83, 683-696.

Crow, T.R. (1988) Reproductive mode and mechanisms for self-replacement of northern red oak (Quercus rubra) - a review. Forest Science, 34, 19-40.

Den Ouden, J., Jansen, P.A. \& Smit, R. (2005) Jays, Mice and Oaks: Predation and Dispersal of Quercus robur and $Q$. petraea in North-western Europe. Seed Fate (eds P.M. Forget, J. Lambert, P. Hulme \& S.B. Vander Wall), pp. 223-240. CABI Publishing, Wallingford. UK.

Forget, P.M., Lambert, J.E., Hulme, P.E. \& Vander Wall, S.B. (2005) Seed Fate: Predation, Dispersal and Seedling Establishment. CABI Publishing. Wallingford. UK.

García, D., Bañuelos, M.J. \& Houle, G. (2002) Differential effects of acorn burial and litter cover on Quercus rubra recruitment at the limit of its range in eastern North America. Canadian Journal of Botany, 80, 1115-1120.

Gómez, J.M., Puerta-Piñeiro, C. \& Schupp, E.W. (2008) Effectiveness of rodents as local seed dispersers of Holm oaks. Oecologia, 155, 529-537.

Gómez-Aparicio, L., Zamora, R., Gómez, J.M., Hódar, J.A., Castro, J. \& Baraza, E. (2004) Applying plant facilitation to forest restoration: a metaanalysis of the use of shrubs as nurse plants. Ecological Applications, 14, $1128-1138$

Herrera, C.M. \& Pellmyr, O. (2002) Plant-Animal Interactions. Blackwell Science, Oxford. UK.

Hulme, P.E. (1994) Post-dispersal seed predation in grasslands: its magnitude and sources of variation. Joumal of Ecology, 82, 645-652.

Janzen, D.H. (1969) Seed-eaters versus seed size, number toxicity and dispersal. Evolution, 23, 1-27.

Janzen, D.H. (1971) Seed predation by animals. Anmual Review of Ecology and Systematics, 2, 465-492.

Li, Q.K. \& Ma, K.P. (2003) Factors affecting establishment of Quercus liaotungensis Koidz. under mature mixed oak forest overstory and in shrubland. Forest Ecology and Management, 176, 133-146.

Lorimer, C.G., Chapman, J.W. \& Lambert, W.D. (1994) Tall understorey vegetation as a factor in the poor development of oak seedlings beneath mature stands. Journal of Ecology, 82, 227-237.

Manson, R.H. \& Stiles, E.W. (1998) Links between microhabitat preferences and seed predation by small mammals in old fields. Oikos, $\mathbf{8 2}, 37-50$. 
Oliver, A.D. \& Chapin, J.B. (1984) Curculio fulvus (Coleoptera, Curculionidae) and its effects on acorns of live oaks, Quercus virginiana Miller. Environmental Entomology, 13, 1507-1510.

Ollerton, J. \& Lack, A. (1996) Partial predispersal seed predation in Lotus corniculatus L. (Fabaceae). Seed Science Research, 6, 65-69.

Pardo, F., Gil, L. \& Pardos, J.A. (2004) Structure and composition of polestage stands developed in an ancient wood pasture in central Spain. Forestry, $77,67-74$.

Pérez, H.E., Shiels, A.B., Zaleski, H.M. \& Drake, D.R. (2008) Germination after simulated rat damage in seeds of two endemic Hawaiian palm species. Journal of Tropical Ecology, 24, 555-558.

Pons, J. \& Pausas, J.G. (2007) Rodent acorn selection in a Mediterranean oak landscape. Ecological Research, 22, 535-541.

Pulido, F.L. \& Díaz, M. (2005) Regeneration of a Mediterranean oak: a wholecycle approach. Ecoscience, 12, 92-102.

Schupp, E.W. (1993) Quantity, quality and the effectiveness of seed dispersal by animals. Vegetatio, $107 / \mathbf{1 0 8}, 15-29$

Steele, M.A., Gavel, K. \& Bachman, W. (1998) Dispersal of half-eaten acorns by gray squirrels: effects of physical and chemical seed characteristics.Ecology and Evolutionary Biology of Tree Squirrels (eds M.A. Steele, J.F. Merrit \& D.A. Zegers), pp. 223-232. Virginia Museum of Natural History, Charlottesville, Virginia. USA

Steele, M.A., Knowles, T., Bridle, K. \& Simms, E.L. (1993) Tannins and partial consumption of acorns: implications for dispersal of oaks by seed predators. American Midland Naturalist, 130, 229-238.

Steele, M.A., Carlson, J.E., Smallwood, P.D., McEuen, A.B., Contreras, T.A. \& Terzaghi, W.B.. (2007) Linking seed and seedling shadows: a case study in the oaks (Quercus). Seed Dispersal: Theory and its Application in a Changing
World (eds A.J. Denis, R.J. Green, E.W. Schupp \& D.A. Westcott),pp. 322 339. CAB Intemational. Wallingford. UK.

Suchomel, J. (2008) Contribution to the knowledge of Apodemus sylvaticus populations in forests of the managed landscape of southern Moravia (Czech Republic). Journal of Forest Science, 54, 370-376.

Vallejo-Marín, M., Domínguez, C.A. \& Dirzo, R. (2006) Simulated seed predation reveals a variety of germination responses of neotropical rain forest species. American Journal of Botany, 93, 369-376.

Vander Wall, S.B. (2001) The evolutionary ecology of nut dispersal. Botanical Review, 67, 74-117.

Vander Wall, S.B. \& Joyner, J.M. (1998) Recaching off Jeffry pine (Pinus jeffreyi) seeds by yellow pine chipmunks (Tamias amoenus): potential effects on plant reproductive success. Canadian Journal of Zoology, 76, 154-162.

Westoby, M., Jurado, E. \& Leishman, M. (1992) Comparative evolutionary ecology of seed size. Tree, 7, 368-372.

Xiao, Z.-S., Harris, M.K. \& Zhang, Z.B. (2007) Acorn defenses to herbivory from insects: Implications for the joint evolution of resistance, tolerance and escape. Forest Ecology and Management, 238, 302-308.

Xiao, Z.-S., Jansen, P.A. \& Zhang, Z.-B. (2006) Using seed-tagging methods for assessing post-dispersal seed fate in rodent-dispersed trees. Forest Ecology and Management, 223, 18-23.

Xiao, Z.-S., Zhang, Z.-B. \& Wang, Y.S. (2005) Effects of seed size on dispersal distance in five rodent-dispersed fagaceous species. Acta Oecologica, 28, $221-229$

Received 23 July 2010; accepted 17 September 2010

Handling Editor: David Gibson 